\title{
The Publishing History of W.H. Smith's Canada: Past, Present and Future: A Preliminary Investigation
}

\author{
Patricia Stone
}

WILlIAM HENRY SMITH, A SURGEON DENTIST ACCORDING TO Rowsell's City of Toronto and County of York Directory (18 50-5I), had arrived in Canada West by $1843 .{ }^{1} \mathrm{He}$ was probably born in England and certainly studied surgery there. According to information on the title page of a later work, he served as surgeon to the emigrant ship Amazon and it is possible that he made his way to Canada in that capacity. ${ }^{2}$

Not long after his arrival, Smith must have begun assembling the information about Canada's upper province which appeared in his first book Smith's Canadian Gazetteer, published in Toronto by H. and W. Rowsell in $1846 .{ }^{3} \mathrm{He}$ claims he spent 'nearly three years' in his quest for information '[visiting] every district, town and village [and walking] over more than three thousand miles of ground'. ${ }^{4}$ The resulting work, with its alphabetically arranged articles on the communities and natural features of Upper Canada, its map, tables, plates, and wealth of information useful to the new settler as well as the established resident, was compiled to 'dispel ignorance and misinformation regarding Canada' and seems to have been a considerable success.

Thus encouraged, Smith embarked upon a more ambitious and detailed publication which was to give the prospective immigrant, as well as the Canadian and British public, a reliable, detailed guide to the past, present and future of Canada West. He states that he sent out hundreds of prospectuses requesting information as well as, once again, '[devoting] a year or two to the collection of a few more facts' through personal visits and observation. ${ }^{5}$ It is possible that he supported himself during the years in which he was assembling both the Gazetteer and his longer work by functioning as an itinerant surgeon. He brings the difficulties of collecting information through personal observation in Canada West vividly to life:

And to arrive at the necessary amount of facts within a given time requires a constant exertion of both body and mind; and a resolution to encounter and to conquer all those various accidents by flood and field that travellers are heir to: - drenching showers, snow storms, mud holes, - dust, broiling sun, thunder storms, - tough beef steaks, damp beds, - loss of luggage and breakages - 
He heaped disdain on the writers of guide books who assembled mere first impressions or, worse, did not encounter the hazards of first-hand investigation at all but simply drew upon facts gathered painfully by other observers:

Oh! ye proteges of Paternoster Row ... who sit cosily at home and write your descriptions under the fostering fig-tree of the Colonial Office and the Board of Trade, we envy you! - we sow the grain, you reap the harvest. ${ }^{6}$

The fruits of all this labour, Canada: Past, Present and Future, offers its readers a wealth of information. The Introduction gives a lengthy history of Canada from Cabot's arrival in 1495 to the events of the I840s. Each county, in geographical order from west to east, is then discussed. Individual settlements are described as to physical characteristics, connecting roads, and important historical events, and accounts are enlivened with quotes from other sources and anecdotes collected from the inhabitants. In conclusion Smith compares Canada with other colonies and speculates on the future potential of the land. The work contains a map of Canada West as well as ten maps of the various counties indicating settlements, roads, railways, harbours, and mills. It also offers commercial tables and information on products, climate, rate of settlement, and trade. In addition a business and professional directory, lists of post offices and clergy in the province, and a geographical index are provided.

The work was apparently planned to appear in ten subscription parts over a number of months beginning late in 1850 . An announcement dated October I850 appeared in the British Colonist stating that the first part would be ready for delivery 'in about a fortnight,' and in the same newspaper on November 26, 1850 , the editor discussed the merits and faults of the first number. The first parts received considerable acclaim from the press in Canada, according to a selection of excerpts brought together later for publication in some copies of the work.

The publisher of this ambitious work, Thomas Maclear, had also arrived in Canada West in the I840s, as a representative of the Glasgow publishing house of Blackie and Son. By 1850 he had established himself as a bookseller and stationer in Toronto and had, in addition, turned his attention to printing and publishing. His work was of sufficient merit to procure for him prizes in letterpress printing in the Upper Canada Provincial Exhibition in $185 \mathrm{I}$ and I852, and his short-lived Anglo-American Magazine (I8 52-55) offered the Canadas a periodical to compete with similar British and American publications.

Announcements of Smith's forthcoming work appeared regularly in the British Colonist and the Toronto Globe through much of $185 \mathrm{I}$ in Maclear's advertisement. In the announcement Maclear offered a copy of the work free of charge to any newspaper which inserted the advertisement and reviewed the parts as they appeared. ${ }^{7}$ The work was to be furnished to subscribers only, 
and a list of subscribers, also assembled for publication in some copies of the work, suggests a wide response. The governor-general subscribed to three copies and, according to Maclear's advertisement in Lovell's Canada Directory (I85I), a committee recommended that the government purchase copies to the value of $£ 50$ on the strength of the usefulness of Smith's Gazetteer. Included in the Toronto list of subscribers were Toronto University and the names of many of the powerful men of the time such as Robert Baldwin, Louis Lafontaine, Francis Hincks, James Leslie, H.J. Boulton, Chief Justice Macaulay, and Bishop Strachan. The list reads rather like an early Who's Who of Canada West as leading citizens from all over the province subscribed along with ordinary individuals. The list contains over 1,400 orders, a rather large printing for the time in Canada. ${ }^{8}$

These orders may have been collected with difficulty, because in May of I85 I Part IV, the part which completed the first volume, according to Maclear's statement on the wrapper, appeared with an admonition to the public. The cost of assembling the work had been 'large beyond conception' and only a very large sale would prevent Maclear and Smith from sustaining a loss. Public duty itself should bring forth subscribers:

[It] is to be regretted that many whose position renders it a matter of moral obligation on them to support so valuable a publication, have not as yet done so; yet it is hoped that they will see the propriety of ordering the work at once, as, after the Subscribers are supplied, every remaining copy will be sent to England - and so the opportunity of possessing the only complete and late account of the 'Land We Live In', extant, will be lost to many whose duty as well as interest it is to have it. ${ }^{9}$

The same advertisement announcing the completion of the first volume informed the public that 'a neatly ornamented Cloth Cover for binding it, is now ready'. The cover could be forwarded to any part of the country through the travellers, or the four parts could be sent to the publication office for binding. A similar arrangement would be available when the second volume was completed 'so that Subscribers need not hesitate to take the parts as issued'.

Maclear's threat of depriving Canada West of any further opportunity for purchasing Canada: Past, Present and Future after subscribers' orders were filled was apparently not carried out. The Echo and Protestant Episcopal Recorder for November 17, I8 54, carried an advertisement for the work with maps and plates, and a work published by Maclear and Co. in I855 offers 'Canada: Past, Present and Future, in 2 volumes, royal 8vo, embellished with Maps and Plates. Price $£$ I IOs'. ${ }^{10}$

Not only were the parts retained and bound but Maclear added plates depicting 'views of the Principal Cities and Towns as well as the most remarkable places in the country' signed by popular artists and engravers such as 
William Armstrong, F.C. Lowe, J. Dyne, E. Whitefield, L. O’Brien, and F.E. Wyman. ${ }^{11}$

II.

I began investigating the publishing history of Canada: Past, Present and Future when my examination of several copies of the work revealed a number of variants. Initially I knew only that the work existed both with plates and without. When I turned to Sabin for guidance he indicated that the picture was a little more complicated. ${ }^{12} \mathrm{He}$ identified three issues:

I. VOLUME I: included 290 pages of text, 80 pages of business directory, a list of subscribers and notices ( 24 pages), 3 folded maps. vOluME II: included 544 pages of text, pages $8 \mathrm{I}-\mathrm{I} 84$ of a business directory, 8 folded maps. This is dated by Sabin, I85I-52.

2. VOLUME I: included 290 pages of text, I 84 pages of business directory, 4 folded maps. VOLUME II: included 544 pages of text and 7 folded maps. This is dated by Sabin, 1852 .

3. VOLUME I: included 290 pages of text, I84 pages of business directory, 5 folded maps and 7 plates. volume II: included 544 pages of text, 6 folded maps and 9 plates. No date is offered.

In addition Sabin gave other features of the three issues:

a) the general map which, according to notices, was to be issued upon conclusion of the work appears in Volume in of the first issue, but in Volume I of later issues.

b) the copyright notice dated I85I is included in Volume II of the earliest issue and in both volumes of the later issues.

The Toronto Public Library's Bibliography of Canadiana describes two copies, no. 33IO, which agrees with Sabin's second issue, and no. 33II, which includes plates but varies from Sabin's third issue in the number of plates and maps in Volume I, the number of plates in Volume II, and in the presence of the general map in Volume II. ${ }^{13}$ Before I began my own search for copies it was evident that at least one variant of one of the issues identified by Sabin existed.

In fact my examination of twenty-seven copies of Volume I and thirty-one copies of Volume II has revealed a surprising number of variants. These variations do not occur in the body of the text, which remains unchanged in every copy I have examined, as far as I have been able to determine. However, in such details as the number of maps, number and subject of plates, elements of the design appearing on the publisher's binding, and the presence and absence of additional material and the copyright date, there is much variation. Some of it no doubt can be explained by the vicissitudes of life endured by a book created to be a guide book: maps may have been torn out for use on a journey and plates removed for framing. However, other variants suggest changes made by the publisher over a period of time and could help to point to a discernable publishing history. The following is a description of the copies I 
examined followed by some speculations on what these copies may tell us about the publishing of this work.

First I present a description of what could be designated basic copies of Volume I and Volume Ir. I have considered a basic copy, in this case, to be one which contains all the essential features which appear in every copy of the work in the same order except for unimportant variations. Following the description of the basic copy is a description of the variants I have noted. As will be seen from the tables which summarize the variants (pp. 58-59), the task of sorting out possible issues and states is complex. In summing up the evidence at the conclusion of this paper, I make some suggestions as to what combination of variations could constitute separate states. Following the presentation of the variants will be found descriptions of a modern reprint of the work by Mika Publishing of Belleville and of those separate parts which I have been able to locate.

Description, Volume I. Basic Copy

Title: CANADA: | PAST, PRESENT AND FUTURE. | BEING A | HISTORI= * CAL, GEOGRAPHICAL, GEOLOGICAL AND STATISTICAL ACCOUNT | OF | CANADA WEST, | BY | W. H. SMITH, | AUTHOR OF THE CANADIAN GAZETTEER; | CONTAINING TEN COUNTY MAPS, AND ONE GEN = ERAL MAP OF THE PROVINCE, | COMPILED EXPRESSLY FOR THE WORK. I [within a pair of double horizontal lines $(3 \mathrm{~cm}$.)] VOL. I. I TORONTO: | THOMAS MACLEAR, 45 YONGE STREET. |

Collation: $8^{\circ}:[\mathrm{A}]^{8}, \mathrm{~B}-\mathrm{G}^{8}, \mathrm{H}^{6}, 2[\mathrm{~A}]^{8}, 2 \mathrm{~B}-2 \mathrm{R}^{8}, 2[\mathrm{~S}]^{8}, 2 \mathrm{~T}^{1}, 3[\mathrm{~A}]^{8}, 3 \mathrm{~B}-3 \mathrm{~F}^{8}, 3[\mathrm{G}]^{8}$, $3 \mathrm{H}_{-3} \mathrm{~L}^{8}, 3 \mathrm{M}^{4}$, [\$I (-AI, $\left.2 \mathrm{AI}, 2 \mathrm{SI}, 3 \mathrm{AI}, 3 \mathrm{GI}\right)$ ]; 300 leaves, pp. [2 pages][i-v] vi-viii [ix] x-xix [Xx, xxi] xxii-xlv, lxvi-lxviii, xlix-cxxiv [I] 2-240 [24I] 242-290 [I] 2-I56 [I57] I58-I77 [178] I79-I84 = 600. Note: Pages xlvi-xlviii misnumbered as lxvi-lxviii.

Signature position: $\mathrm{C}$ keel, 2B returning, $2 \mathrm{M}$ accepted.

Contents: Half title engraving: [arched and ornate] CANADA, | PAST, PRESENT \& FUTURE; | [steel engraving of Niagara Falls] | [below engraving] Niagara falls | TORONTO | PUBLISHED BY THOMAS MACLEAR | ; v. blank; [i] title page; [ii] blank; [iii] dedication [gothic] TO | [gothic] The People of Canada, | THROUGH WHOSE ENTERPRISE AND INDUSTRY THIS PROVINCE MUST ONE DAY | ATTAIN A HIGH RANK IN THE SCALE OF NATIONS, | THIS WORK | IS INSCRIBED | BY THEIR FRIEND AND SERVANT, | THE AUTHOR. | ; [iv] blank; [v]-viii Preface; [ix]-xix Index to Volume I; [xx] blank; [xxi]-lxxi INTRODUCTION / [wavy line $(3.4 \mathrm{~cm}$.)] CHAPTER I. | ; lxxii-cvi CHAPTER II.; cvii-cxxiv CHAPTER III.; [I]-85 CANADA: | PAST, PRESENT AND FUTURE. | ESSEX, KENT, AND LAMBTON. | ; 85-108 MIDDLESEX.; I09-II7 OXFORD.; II8-I52 NOR= FOLK.; 153-2I8 LINCOLN, HALDIMAND, AND WELLAND.; 219-270

* The sign $=$ indicates a hyphen not in the original. 
WENTWORTH AND HALTON.; 270-290 YORK.; [I]-I56 BUSINESS DIRECTORY |[gothic] Of Canada West. | ; [157]-167 LIST OF POST OFFICES | IN CANADA WEST. | ; I68-I77 LIST OF CLERGY AND MINISTERS | Of various denominations in Canada West. $\mid$; [178]-I84 Additions to Directory of Canada West. | .

Note: The Niagara Falls engraving closely resembles an engraving in Bartlett's Canadian Scenery.

Maps: 3 folded maps, copper engraved, ranging between $20.5 \times 27 \mathrm{~cm}$. and $22 \times 27.8 \mathrm{~cm}$.; maps are illustrative of the counties discussed in the text and are placed at the beginning of the relevant discussion; facing p. [I] Counties of | ESSEX, KENT, | AND | LAMBTON. | ; facing p. 85 Counties of | MIDDLESEX, | OXFORD, | AND | NORFOLK. Toronto. Thomas Maclear. | ; facing p. I53 Counties of | LINCOLN, HALDIMAND, WELLAND, | WENTWORTH AND HALTON. | Toronto. Thomas Maclear. | Each map is within a thick-thin frame and contains a legend and a scale of miles.

Typography: Signed, Roman capitals centred at foot of page. Pagination in headlines at outer margin of type-page. Running-titles in Roman capitals; chapter or section titles on recto and verso; text 42ll.; Roman type.

Paper: White wove unwatermarked, all edges cut and undecorated, $15.2 \mathrm{x}$ 24. $\mathrm{I} \mathrm{cm}$.

Casing: Overall; Material: vertical rib grain cloth-covered boards in red, green, or black. Upper case: blind-blocked double frame with blind-blocked triangular design of small, trailing flowers in each corner $(4 \times 7.4 \mathrm{~cm}$.); central ornament stamped in gilt, $(8.6 \times 8 \mathrm{~cm}$.), [side view of a beaver on a leafy bank facing left] | [within curved ribbons, knotted each side] PAST PRESENT | [central in the device] CANADA | [within curved ribbons] AND FUTURE | (see p. 62) . Back strip: divided into six compartments by horizontal blindblocked lines; [ 2nd compartment] SMITH'S | CANADA | [4th compartment] VOL. I |, all stamped in gilt. Lower case: framing and corner designs as for upper case; central ornament blind-blocked, $(5.4 \times 8 \mathrm{~cm}$.), oval with radiating spokes of flowers and decorations. Endpapers: range from light cream to creamy yellow brown; heavier weight than sheets. Some copies have I leaf between endpaper and half title; some copies have I leaf between end of text and endpaper. In each case leaf is blank and is of the same weight as the paper used for the text.

\section{Description, Volume II. Basic Copy}

Title: CANADA: | PAST, PRESENT AND FUTURE, | BEING A | HISTORI= CAL, GEOGRAPHICAL, GEOLOGICAL AND STATISTICAL ACCOUNT | OF | CANADA WEST, | BY | W.H. SMITH, | AUTHOR OF THE CANADIAN GAZETEER; | CONTAINING TEN COUNTY MAPS, AND ONE GEN = ERAL MAP OF THE PROVINCE, | COMPILED EXPRESSLY FOR THE WORK. I [within a pair of double horizontal lines $(3 \mathrm{~cm}$.)] VOL. II. I 
TORONTO: | THOMAS MACLEAR, 45, YONGE STREET. | .

Collation: $8^{\circ}: \pi \mathrm{I} 2,[\mathrm{~A}]-2 \mathrm{~L}^{8},[\$ \mathrm{I}(-\mathrm{A})] ; 284$ leaves, pp. [i-v], vi-xix [xx, xxi] xxii-xxiv [I]-204 [205] 206-544 $=568$.

Signature position: $\mathrm{H}$ and, $\mathrm{N}$ Company, $\mathrm{C}_{2}$ consists.

Contents: [i] Half title: CANADA: | PAST, PRESENT, AND FUTURE | ; [ii] blank; [iii] title; [iv] [between horizontal double lines (Io.5 cm.)] ENTERED, according to Act of the Provincial Legislature, in the year of our | Lord one thousand eight hundred and fifty-one, | BY THOMAS MACLEAR. I In the office of The Registrar of the Province of Canada. | ; [v]-xix Index to Volume II; [xx] blank; [xxi]-xxiv ADDITIONS AND CORRECTIONS; [I]-50 COUNTY OF YORK; 5I-90 SIMCOE; 9O-I3I WATERLOO; I3I-I99 HURON, PERTH, AND BRUCE; 199-266 NORTHUMBERLAND AND DURHAM; 227-240 PETERBOROUGH; 24I-270 HASTINGS; 270-3I5 FRONTENAC, LENNOX AND ADDINGTON; 3I6-353 LANARK AND RENFREW; 353-375 CARLETON; 375-384 PRESCOTT AND RUSSELL; 384-398 STORMONT, DUNDAS AND GLENGARRY; 399-4I7 CANADA - ITS NATURAL PRODUCTIONS; 4I8-427 CANADA - ITS CLIMATE AND PRO= DUCTIONS; 428-464 CANADA: AND OTHER COLONIES COMPARED; 465-5I5 CANADA: ITS PROGRESS AND IMPROVEMENT; 5I6-544 HINTS TO EMIGRANTS.

Maps: Six folded maps, copper engraved, ranging between $20.6 \times 27.3 \mathrm{~cm}$. and $22.2 \times 28.3 \mathrm{~cm}$. Maps are illustrative of the counties discussed in the text and are placed at the beginning of the relevant discussion. Facing p. 90 Coun $=$ ties of | WATERLOO, | HURON, PERTH, | AND | BRUCE | Toronto. Thomas Maclear. | ; facing p. I99 Counties of | PETERBOROUGH |DURHAM, |AND | NORTHUMBERLAND. | ; facing p. 24I Counties of | HASTINGS, FRON= TENAC, | LENNOX AND ADDINGTON. | ; facing p. 256 County of | PRINCE EDWARD. | Toronto. Thomas Maclear. | facing p. 3 I6 Counties of | LANARK AND RENFREW, | CARLETON AND LEEDS, | AND | GREN = VILLE. | Toronto. Thomas Maclear. | ; facing p. 375 Counties of | PRESCOTT AND RUSSELL, | AND | STORMONT, DUNDAS, | AND | GLENGARRY. | Toronto. Thomas Maclear. | .

Typography and Paper: As for Volume I except that the signature is not consistently centred at the bottom of the page, i.e., A-E, central; F-Y, to right; Z-L2 to left.

Casing: As for Volume I.

\section{Variants}

Pages 58-59 present charts which display the variants for Volumes I and II separately for ease of comparison. One item which is not a variant, the presence or absence of stab holes, is recorded to help determine which copies could be made up from parts. It is important to remember, nonetheless, that 
the presence of stab holes can be difficult to determine in books which are tightly bound. The evidence must not be considered definitive.

Variants. Volume I (see chart, page 58)

I. HALF TITLE:

i. Half title without engraving. See description of half title for Volume II. Only I example of this.

ii. Absence of half title.

2. TITLE PAGE:

One example of a title page from Volume ir altered to read Volume I.

3. MAPS:

i. Additional maps:

a. Folded map, copper engraved; $21.6 \times 28.4 \mathrm{~cm}$.; facing p. 270 , Counties of $\mid$ YORK AND SIMCOE. | Toronto. Thomas Maclear. | .

$b$. Folded map, copper engraved; $57.8 \times 42 \mathrm{~cm}$.; between viii and [ix] MAP OF $\mid$ CANADA WEST OR UPPER CANADA $\mid$ COMPILED FROM $\mid$ Govern = ment Plans, Original Documents, and Personal Observation |BYWilliam $H$. Smith, | Author of the Canadian Gazetteer, for Canada | PAST, PRESENT, AND FUTURE. | TORONTO. | Published by Thomas Maclear, | I852. | . British coat of arms centre top, legend and scale.

ii. Variation in the number of basic county maps. 2 copies examined had only 2 basic county maps; I had no basic county maps; I had an additional basic county map, Peterborough, Durham and Northumberland, normally found in Volume II. See Volume II, Maps, for description.

4. CASING DECORATION VARIANT (see p. 63):

Casing: Upper casing: as for the basic copy except that the beaver is heavier and rather ferocious and the surrounding vegetation is scant. Lower casing: as for the basic copy except that the central design is smaller and less ornate.

5. ADDITION OF COPYRIGHT DATE:

i. Contents: [between wavy lines (I0.7 cm.) on title page verso] ENTERED, according to Act of the Provincial Legislature, in the year of Our Lord | One thousand eight hundred and fifty-one, by THOMAS MACLEAR, in the Office | of the Registrar of the Province of Canada. | .

ii. One example of the copyright notice being as for Volume II. This is the copy which has an altered title page from Volume II.

6. PARTIAL BUSINESS DIRECTORY COUPLED WITH ADDITION OF SUBSCRIBERS' LIST AND NOTICES:

Contents: Following text pp. [I]-290, [I ]-80 of the Business Directory; [I ]-I7 FIRST LIST OF SUBSCRIBERS | TO | CANADA: | PAST, PRESENT AND FUTURE. | ; I8]-24 SELECTIONS FROM NOTICES OF THE WORK.|. 


\section{ADDITION OF ENGRAVINGS:}

Plates: Wood engravings on light brown paper; most are full page and are placed in the text to illustrate the subject being discussed. Not every plate appears in each of the 3 copies with plates which I have located and examined. In 2 cases the plates were apparently identical but the engraving titles varied somewhat (see Quebec and Hamilton plates). See accompanying chart, page 60 , for engraving titles, variations in titles, location of plates, and signatures of artists and engravers.

Variants. Volume II (see chart, page 59)

I. HALF TITLE:

I4 out of 3 I copies examined have no half title.

2. MAPS:

i. Additional maps:

a. Folded map of York and Simcoe, usually located facing p. [I]. See description under Volume I, Variant 3 ia.

b. Map of Canada West. See description under Volume I, Variant 3ib, except that the location is usually before the title page.

ii. Variation in the number of basic county maps from $I$ to 6.

3. ADDITION OF PART OF THE BUSINESS DIRECTORY:

Contents: Following conclusion of text p. $544 ; 8 \mathrm{I}-\mathrm{I} 84$ portion of the Business Directory and all following material. See Volume i Contents for description.

\section{ADDITION OF ENGRAVINGS:}

Plates: Description as for Volume I, Variant 7. Considerable variation in engraving titles occurs. Not every engraving appears in every copy which has engravings. On the one occasion in which it was possible to compare plates (in the Lorne Pierce Collection, Douglas Library, Queen's University) some evidence of re-engraving seemed present in the Kingston plate. See accompanying chart, page 6I, for engraving titles, variations in titles, locations of plates, and signatures of artists and engravers.

5. CHANGE OF LOCATION OF INDEX AND ADDITIONS AND CORRECTIONS:

Index to Volume II and Additions and Corrections are placed following $\mathrm{p}$. 544 , the conclusion of the text, instead of immediately after the title page. Two examples of this have been located.

\section{ADDITION OF BINDING INSTRUCTIONS:}

Contents: Following Additions and Corrections xxi-xxiv; [small leaf] BINDING "SMITH'S CANADA." | ; a description of the cloth covers is given; subscribers are advised not to have the work bound in leather for at least three months as 'the last sheets of the work are just printed ... [and] the pressure 
necessary is apt to disturb the ink; and thus very much injure the appearance of the pages'; binders are instructed to put the whole of the Business Directory at the end of Volume $I$ in order to equalize the size of the volumes; the proper location in the text for the various maps is given. Only one example, the Royal Military College copy, has been found.

\section{Modern Reprint. Volume I}

Title: CANADA | Past, Present and Future | BY | W.H. SMITH | VOL. 1 | [bottom of page] Mika Publishing | Belleville, Ontario | 1973 | .

Contents: Upper end paper; [i] CANADIANA | Reprint Series No. 59; [ii] blank; [iii] half title, CANADA | Past, Present and Future | ; [iv] blank; [v] title page ; [vi] Originally published in I852 | by Thomas Maclear, 45 Yonge St.,

Toronto | Facsimilie edition | by Mika Publishing | Belleville, Ontario | IsBN 0-919302-70-X | I973 |; [vii], [viii], Introduction; [Reprinted text follows as in basic copy with maps and plates as indicated in the chart, page 58.]

Casing: Red, mottled, raised pattern, cloth-covered boards. Upper case: central design, a 'ferocious' beaver above an oval design of ribbons with the title, an imitation of the design discussed in Volume I, Variant 4; Back strip: SMITH'S | CANADA | VOL. I | MIKA | ; Lower case: no design.

\section{Modern Reprint. Volume II}

Title: CANADA | Past, Present and Future | BY | W.H. SMITH | VOL. 2 | [bottom of page] Mika Publishing | Belleville, Ontario | 1974 | .

Contents: Upper end paper; [i] CANADIANA | Reprint Series No. 67 | ; [ii] blank; [iii] half title, CANADA | Past, Present and Future $\mid$; [iv] blank; [v] title page; [vi] Originally published in 1852 | by Thomas Maclear, 45 Yonge St., Toronto | Facsimilie edition | by Mika Publishing | Belleville, Ontario|ISBN 0-919302-78-5 | I974 |; [Reprinted text follows as in basic copy with maps and plates as indicated in the charts, pages 59 and 6r.]

Casing: As for Volume I except for Vol. II on back strip.

\section{Parts and Numbers}

Maclear stated, in an advertisement on the inside lower wrapper of some of the parts, that the work 'will be completed in about ten parts'. I have not located all ten parts, if, indeed Maclear did issue the work in ten. Those that have been examined are, in some cases, in good condition with wrappers attached and in several instances have loose or missing wrappers. Most parts consist of some text, a portion of the business directory, and a map. Two are called Numbers and the rest, Parts. Maclear states in the same advertisement on the lower wrapper that 'the work will be issued in numbers at Is. $3 \mathrm{~d}$. each and parts, of double size, at 2 s. $6 \mathrm{~d}$. each'.

The following descriptions reveal some further problems in tracing the 
publishing history of Smith's work. The implications of these problems will be discussed later. Where I have seen more than one copy of a part, I discuss all copies together if there are differences to record. The descriptions are given in numerical order, parts first, then numbers. The descriptions cover only paging, maps, and wrappers as the text remains unchanged. For other details the descriptions for Volumes I and II, Basic Copy, should be consulted.

Description of Parts which have been located:

PART II: COPY I

Contents: Pp. II 3-208 text Volume i; pp. [I]-16 Business Directory.

Map: Counties of Peterborough, Durham and Northumberland, facing $\mathrm{p}$. II3.

Wrappers: Light brown paper wrappers. Upper wrapper: see illustration page 64 for detail, which is printed in black. Inside upper wrapper: [between pairs of lines (I2.3 cm.); gothic] 'Elgin Association.' | ; this is an addition inserted by the publisher from information given by Reverend W. King. Lower wrapper: Thomas Maclear advertisements. Inside lower wrapper: CANADA: | PAST, PRESENT AND FUTURE. | , a description of the projected work for advertising purposes.

PART II: COPY 2

Contents: As for Copy I.

Map: Missing, but there is evidence of a leaf torn out facing page II3.

Wrappers: Upper wrapper: as for Copy I. Inside upper wrapper: blank. Lower wrapper: as for Copy I. Inside lower wrapper advertisement: VAN = KOUGHNET \& PRINGLE, | BARRISTERS AND ATTORNEYS-AT-LAW | Hughson Street, | HAMILTON |.

PART III: COPY I

Contents: Pp. I93-288 text Volume II; pp. 8I-96 Business Directory.

Map: Counties of Waterloo, Huron, Perth and Bruce, facing p. I93.

Wrappers: Upper and lower wrappers: as for Part II. Inside upper wrapper: blank. Inside lower wrapper: advertisement Vankoughnet and Pringle, as for Part II, Copy 2.

Note: Roman III in Part III stroked out by hand with a black ink and figure 7 entered by hand beside it. The figure is characteristic of a nineteenth-century numeral.

PART III: COPY 2

Contents: Pp. 209-288 text Volume I; pp. 17-48 Business Directory. Map: Missing, but there is evidence of a leaf torn out facing page 209.

Wrappers: Upper wrapper loose, however rough edges of wrapper mesh 
properly with rough edges along spine; also a stain on the spine extends onto the upper wrapper: as for Part II, Copy I. Inside upper wrapper: blank. Lower wrapper and inside lower wrapper: as for Part II, Copy I.

PART IV:

Contents: Title page Volume $\mathrm{I}$; verso: copyright as for Volume $\mathrm{I}$; dedication, preface, index to Volume I, introduction; pp. [i]-cxxiv, and pp. 289 and 290 Volume I.

Map: Counties of Lincoln, Haldimand, Welland, Wentworth and Halton, facing title page.

Wrappers: Upper wrapper: as for Part II except that the words PUBLISHED BY are eliminated from the lower centre and THOMAS MACLEAR, 45 YONGE STREET is spaced to fill the area. Inside upper wrapper: blank. Lower wrapper loose, but rough edges of wrapper and spine mesh properly: [to extreme upper right] 45 YONGE STREET, | TORONTO, May, 1851. | [across entire page] CANADA: PAST, PRESENT, AND FUTURE. | COMPLETION OF THE FIRST VOLUME. I ; the publisher states that a 'Cloth Cover for binding' is ready, urges further subscriptions, and issues instructions to the binders (see page 67). Inside lower wrapper: an advertisement for a work to be published by Maclear: IN THE PRESS, AND WILL SHORTLY BE PUB= LISHED, | 'DERRYANA:' | BEING A HISTORY IN PROSE AND VERSE | OF THE | SIEGE OF LONDONDERRY, AND DEFENCE OF ENNISKILLEN, | In I688 and I689, | BY THE REV. JOHN GRAHAM, A.M., | Rector of Lifford, near Londonderry. [Wavy line]; followed by a description of the work.

PART V:

Contents: Pp. [ I]-80 text Volume II: pp. 49-80 Business Directory; a fourpage advertising insert for the Imperial Gazetteer.

Plate: Engraved half title Niagara falls., protected by tissue paper, facing inside upper wrapper.

Wrappers: Upper wrapper: as for Part IV with instructions regarding delayed map at the bottom of the page instead of THOSE TAKING.... Inside upper wrapper: blank. Lower wrapper: JUST PUBLISHED. | [printer's device] | [in decorative type ressembling pieces of branches] DERRIANA, $\mid$; continues with a description of the work and author. Inside lower wrapper: advertisement for a number of works published by Blackie and sold by Maclear.

Description of Numbers which have been located:

No. 3:

Contents: Pp. 369-448 text Volume II; pp. I29-I60 Business Directory and List of Post Offices in Canada West; I leaf advertising insert. 
Maps: Counties of Lanark ...; County of Prince Edward, between upper wrapper and p. 369.

Wrappers: Upper wrapper: as for Part II, except that No. replaces PART, the number is given in arabic not roman numerals, and the price is Is. $3 \mathrm{~d}$. Inside upper wrapper, lower wrapper, and inside lower wrapper: as for Part II, Copy I.

Note: The number 3 on the upper wrapper has been written over by hand in black ink to read 9. The Is. has similarily been changed to 2 and the 3 d. to 6 . All figures characteristic of nineteenth-century numerals.

No. [?]:

Contents: Pp. 289-368 text Volume II; pp. 97-128 Business Directory.

Map: Counties of Hastings, Frontenac, Lennox and Addington, facing p. 289.

Wrappers: Upper wrapper: as for Part II except No. replaces PART and price is Is. $3 \mathrm{~d}$. Inside upper wrapper: CANADA: PAST, PRESENT, AND FUTURE. | [wavy line] | [hand with pointing finger] In consequence of the unavoidable delay in collecting the necessary | information, the matter relating to Canada generally, with the I new Map of the Province, Title-page, Introduction, \&c. (which, | when bound, will form the COMMENCEMENT of the work, ) will be I properly paged, and contained in the last Part issued. I . Lower wrapper: advertisements, two being dated Oct. I850. Inside lower wrapper: as for Part II, Copy I.

Note: The number on the upper wrapper has been written over by hand in black ink to read 8 . The is. has similarly been changed to 2 and the $3 \mathrm{~d}$. to 6 . All figures are characteristic of nineteenth-century numerals.

OTHER PARTS AND WRAPPERS:

I have also found three parts without wrappers, two loose lower wrappers, and one loose upper wrapper, but have not been able to combine parts and wrappers with any certainty. The parts include:

I. Pp. I-I 2 text Volume I, map of Essex, Kent and Lambton.

Note: This could be Part I or Number I. One review quoted in the Selections from Notices (p. 18-23) states that the 'first number of this work, now before us, describes the County of Essex and the United Counties of Kent and Lambton'. Another states, 'The author of this work has handed us the first part .... And yet another, 'This is the first number of a work to be issued in parts ... descriptive of the Counties of Essex, Kent, and, Lambton.'

2. Pp. II3-208 text Volume I, map of Peterborough, Durham and Northumberland.

3. Pp. I93-288 text Volume II, map of Waterloo, Huron, Perth and Bruce. 
Upper Wrapper:

Part IV, as in the above description for Part IV and with the verso blank.

Lower Wrappers:

I. As for No. [?] above. There is some evidence that this may belong to the part which may be Part I or Number I.

2. As for No. [?] above.

The following summary, indicating what has been examined and what can probably be conjectured, should help to organize the information about the parts in a more useful form.

\section{Summary of the Parts}

CONTENTS

ON WRAPPER

I. Vol. I t.p., preface, index Vol. I,

(63 leaves) Part Iv

Introd., pp. [i]-cxxiv, pp. 289, 290

2. ? [Vol. I pp. [I]-II2 $\quad$ (56 leaves) Part I?]

3. Vol. I pp. II 3-208, directory pp. I-I6

(56 leaves) Part II

4. Vol. I pp. 209-288, directory pp. 17-48

(56 leaves) Part III

5. Vol. II h.t. engraving, [I]-80, directory 49-80

(56 leaves) Part v

6. ?[Vol. II pp. 8I-I92

[56 leaves) Part vi?]

7. Vol. II pp. I93-288, directory, pp. 8I-96

(56 leaves) Part III (7 in ink)

8. Vol. Il pp.289-368, directory pp. 97-I28

(56 leaves) No. [?] (8 in ink)

9. Vol. II pp. 369-448, directory pp. I29-I60

(56 leaves) No. 3 (9 in ink)

Io. ? [Vol. II p. 449-544, directory and additions

pp I6I-I84

(60 leaves) Part $\mathrm{x}$ ?]

III.

The above summary suggests that an orderly progression in the publishing of ten parts probably took place in spite of the uncertainty that is first caused by the confusing use of 'No.' and 'Part' on the wrappers. Some of the other information on the wrappers helps to sort out the problem, which might be explained in the following manner.

In spite of Maclear's statement that he would offer both parts and numbers to his subscribers, we cannot state with certainty whether he began issuing the work in parts or numbers or both until further copies of pp. [I]-II2, Volume I of the text are discovered. As we have seen, the critical notices do not clarify the situation. We do know that Parts II, III, IV, and v were issued and probably in that order, and the newspapers of the time attest to the arrival 
of all the parts up to the conclusion of Volume I, as quoted in the Notices which Maclear added to some copies of Volume I. It is possible to hypothesize a Part VI (pp. 8I-I92, Volume II) as can be seen in the summary above.

The difficulties begin with finding pp. I93-288 of Volume II called Part III and subsequent parts offered as No. [?] and No. 3. Though normally it is wise to give little significance to handwritten additions to a work, I believe that here we must consider the emendations, for it is possible that they were done upon the instructions of the publisher. Quite early into publication Maclear may have decided that he would prefer to offer only parts. This left him with some wrappers already printed with numbers and lower prices. Rather than destroy these, Maclear may simply have employed them to serve as wrappers for later parts and altered the information by hand.

The above conjectures are supported by evidence on the inside upper wrapper of both numbers that I have seen. Number [?] contains the strange statement that there will be a delay in issuing the 'Commencement' of the work. This number actually contains pp. 289-368 of Volume II and in all probability was issued some months after Part IV appeared announcing the completion of Volume I and offering that very 'Commencement.' Number 3 (pp. 369-448, Volume II) contains an announcement about the Elgin Association, which also appears in the same location in Part II but in none of the other parts. This suggests that Maclear prepared both wrappers about the same time and added the information to supplement material which appeared on page 29 of Part I and possibly No. I. Both of these situations suggest that the wrappers were prepared to be used early in publication.

If I have interpreted the evidence of the parts correctly, it suggests that the first state of Canada: Past, Present and Future would look like the summary on page $5 \mathrm{r}$. Sometime in November of 1850 Thomas Maclear issued Part I and Nos. I and 2?) of Volume I, the description of Essex, Kent and Lambton. Parts II and III continued with descriptions of other western counties. The Business Directory began appearing with Part II. Possibly by the time Part II appeared Maclear decided to offer only parts, thus he had wrappers printed for No. 3 to use up later. Maclear used the lower wrapper to advertise his retail business and to promote the sale of Canada: Past, Present and Future. He also corrected information in Volume I by means of an inside upper wrapper for Part II and No. 3 .

By May of I85I Part IV appeared giving the introductory material, but the engraved half title was not available until Part $v$ appeared. The casing for the first volume was announced as being ready and a similar casing for Volume II was promised for the conclusion of the second volume. With Part $v$ the second volume was in progress. At least by the appearance of Part viI, Maclear began to use leftover wrappers with parts and numbers altered simply by hand. Part $\mathrm{x}$ concluded the text, possibly early in $\mathrm{I} 852$, as the Canada West map, which might have appeared in that last part, is dated 1852 . In general one map 
appeared with each part, although occasionally a map would be late in arriving and would have to be included in the next part.

These conjectures about the publication of Smith's work obviously make some assumptions about the sequence in which the parts appeared and could be incorrect. The only fixed dates we have are November I8 50 for Part I, May I85 I for Part IV, and I852 for the Canada West map, and in the latter two cases we are relying on dates in the publication, not necessarily trustworthy information.

Maclear had stated that once all the parts had been printed and his subscribers had been supplied, all remaining copies would be sent to England. The evidence certainly refutes this. If some did go to England, and it would be interesting to investigate this, a number must have remained with Maclear. Using the evidence from the variants it is possible, once again, to conjecture about several different states of the work that may have appeared.

Some of the variants recorded are probably of no significance and will be of no assistance in sorting out possible states or issues. These include the variation in the numbers of basic maps in each volume, which, as I have pointed out, could be simply a matter of their removal by early owners. The same applies to the two examples of the change in location of the Index and the Additions and Corrections in Volume II - possibly attributable to some local binder's decision - and the isolated (but fortunate) case of the addition of the binding instructions.

The examples of a Volume in half title used in Volume $\mathrm{I}$ and the alteration of a Volume II title page for use also in Volume i occur too infrequently to be useful in determining possible changes in state. Each is an isolated case which could be explained by some last minute substitution at the binder's or publisher's.

The page of instructions to the binder, unimportant as a variant in itself, does allow us to consider what one state of the work intended by the publisher might have been and to fit in two more significant variants, the Canada West and York County maps. If these binding instructions did come with the last part, as the announcement of the printing of the last sheets in the body of those instructions makes probable, then we know at least that at one time Maclear intended the Canada West map and the York map, as well as the entire Business Directory, to be bound in Volume I. Thus the description of the basic copies of Volumes I and II with the additions of Variants $3 i a$ and $b$ would give us a possible first state.

Another important variant which seems to point to another state of the work is the appearance of the List of Subscribers and Notices. As can be seen from the chart on page 58 , these are always paired with the first half of the Business Directory at the conclusion of Volume I, except in the Mika reprint, which is a special case and will be discussed later. This is the only consistent correlation I have found in this work and certainly suggests that it has come 
about through the decision of the publisher. Even if a new set of binding instructions had gone out, one out of twelve binders would probably have got it wrong or been instructed to keep the Directory together by the owner of the work. Indeed to split the Business Directory where it is split in every case is awkward. The merchants of Simcoe County are sliced off in the course of the letter ' $M$ ', not to continue until after p. 544 in Volume II.

Of the twelve copies of Volume I which include a partial Business Directory, Subscribers' List, and Notices, not one contains either the Canada West map or the York map. There are a number of copies of Volume II with a partial Business Directory and York and Canada West maps which could make up sets with this state of Volume I.

The absence of the Canada West and York maps from particular copies may have nothing to do with the publisher's intentions, but their presence in Volume II, when we have seen that, at one stage in the course of publishing, they were intended to appear in Volume I, probably signifies something more than an accident of binding, especially as the maps are found in the same location on every occasion except in one erratically assembled copy.

The evidence seems to point to another state of Smith's work. It is not unlikely that at some point Maclear decided to issue the Subscribers' List and Notices to encourage sales, possibly after all the parts had been issued, in order to get rid of the parts which had not been sold. By this conjecture, this new state, consisting of Volumes I and II as in the basic description, with Variants 6 , Volume I, and 2ia and $b$ and 3 , Volume II, would then probably be a second state. This argument is strengthened by the absence of the Subscribers' List and Notices from the parts I have examined, which suggests that the List and Notices appeared later, and also by the binding instructions which were said to be issued with the last sheets of the work and which make no mention of the List or Notices.

There is, however, an argument for the state just described being an early state, in that none of the reviews in the Notices mentions any part later than Part IV. The actual sequence of the two states which I have identified must remain uncertain at present.

The presence of plates in Canada: Past, Present and Future clearly marks another state. We know that Maclear was advertising the work with plates in I854 and I855, possibly earlier, though I have yet to locate an announcement. As will be seen from the charts on pages 58-59, the three copies of Volume I with plates that I have seen always appear with a full Business Directory, and Volume II with plates always appears without a Business Directory. It seems that Maclear had chosen to return to an intact Directory and no longer wished to use the Subscribers' List and Notices. He was probably relying upon the plates to stimulate sales of what may have become an inventory of parts that he would like to dispose of. The work, after all, had first begun to appear 
in the fall of 1850 and it is clear from the text that the type had not been reset by 1855 - if that is the approximate year in which the illustrated state appeared. Maclear also possibly had plates available which had been prepared for the Anglo-American Magazine, a publication which had ceased in $1855 .{ }^{14}$

As can be seen from the charts describing the plates, Maclear was not consistent in the plates he used nor in the captions he appended. Again the absence of a plate in the chart may not be significant: plates may be absent because they were later removed. The presence of differences could indicate some variant or change in state, or perhaps merely inconsistency in publishing practices. Volume II offers the greater inconsistencies: two copies have a View of London before the title page, one has Cedar Rapids - River St. Lawrence; the same plate simply titled Cedar Rapids appears much later in the text in two other copies; the Cobourg plate appears in the same place in every copy but sports three different captions, one of which clearly has nothing to do with this work (page I7 of Volume II discusses Milton, Mimico, and Etobicoke). I think that taken altogether the evidence of the charts on pages 58-59 and the lack of correlation with other variants suggest a rather casual approach to the assembly of the work rather than a conscious desire on behalf of the publisher to bring out different states and that therefore Canada: Past, Present and Future with plates, in whatever number and location, represents a third and later state that we can identify.

No consistent correlation with other variants was discovered for the two different beaver on the casing of Volume I, the presence and absence of the copyright date in Volume I, or the absence of the half title in Volume II. The significance of these three variants in the publishing history of Smith's work remains uncertain at present.

Many an innocent-looking Canadian work may cause the unsuspecting bibliographer much trouble when he attempts to establish the various states in which it may be found and what these indicate about the author's and publisher's intentions. Mika Publishing Company, in offering a reprint of Canada: Past, Present and Future, seems to have fallen into the trap of thinking that the task was a straightforward one. I was informed that the Company used copies of the work from the Douglas Library to make its facsimiles. It issued a Volume I with a complete Business Directory, a List of Subscribers and Notices, and the York and Canada West maps, a combination which I have never seen. Volume II of the reprint offers eight plates and thus presents a later state than Volume I. I was unable to discover the original for either in the Douglas Library Collection and suspect that the reprint may, in fact, be a combination put together from several different copies. It is laudable that Mika Publishing Company wished to reissue the work for today's reader, but it is apparent that the work never did come out of Maclear's office in this form. 
The bibliographic study of Canada: Past, Present and Future is not yet complete. I shall welcome any new information or interpretation that readers may be able to offer. One thing is clear: the study of nineteenth-century publishing in Canada will never be an easy task if other publishers carried on their business in as expedient a fashion as Thomas Maclear.

NOTES

Elizabeth Hulse, whose Dictionary of Toronto Printers, Publishers, Booksellers and the Allied Trades, 1798-1900 is to be published in I982, provided information on Thomas Maclear and invaluable assistance with many problems.

I. Biographical information on W.H. Smith is based upon William F.E. Morley's account in the Dictionary of Canadian Biography, vol. x, pp. 660-I, and his preface to the Mika Publishing Company's reprint described in this paper. In addition the prefaces and title pages of Smith's three works have provided information.

2. W.H. Smith, Smith's Family Physician (Montreal, I873), title page.

3. W.H. Smith, Canadian Gazetteer Comprising Statistical and General Information Respecting All Parts of the Upper Province, or Canada West (Toronto, 1846).

4. Ibid., title page and preface.

5. W.H. Smith, Canada: Past, Present and Future. Being a Historical, Geographical, Geological and Statistical Account of Canada West ... (Toronto, I85I), vol. I. p. vi.

6. Ibid., preface, p. vii.

7. Hugh Scobie, editor of the British Colonist, in a review of the first part on Nov. 26, I850, in his newspaper, criticized the work for lack of original material. Maclear responded on Nov. 29 pointing out that only a minimum of material had been included from the Gazetteer. Scobie and Maclear were to a certain extent rivals in Toronto bookselling and publishing, and it is interesting that only a few years later, on Scobie's death, Maclear took over his business.

8. The large number of copies reported to the Union Catalogue at the National Library of Canada supports the probability of a large printing.

9. Canada ..., part IV, lower wrapper.

Io. G. Auchinleck, A History of the War Between Great Britain and the United States of America (Toronto, I855). See Maclear's advertisements.

II. Echo and Protestant Episcopal Recorder, Nov. 17, I854. See Maclear's advertisements.

I2. Joseph Sabin, A Dictionary of Books Relating to America, from Its Discovery to the Present Time (Amsterdam, 1962), vol. xxI, pp. 187-8.

13. Toronto Public Library, A Bibliography of Canadiana: Being Items in the Public Library... Relating to the Early History and Development of Canada, ed. F.M. Staton and M. Tremaine (Toronto, I934), p. 590.

I4. I have seen the same plates and captions in Smith's work and the Anglo-American Magazine. See vol. I, no. 2, Aug. 1852, and subsequent months to May I8 53 for 1o plates which also appear in Canada...

Illustrations courtesy of the Thomas Fisher Rare Book Library, University of Toronto. 


$\begin{array}{ll}\text { Register of Copies Examined } \\ \text { OBA } & \text { Barrie Public Library } \\ \text { OHM } & \text { McMaster University, Hamilton } \\ & \text { Mills Memorial Library Rare Book Dept. } \\ \text { OKQ } & \text { Queen's University, Kingston } \\ & \text { Douglas Library, Lorne Pierce Colln. } \\ & \\ & \\ \text { OKR } & \text { Royal Military College, Kingston } \\ \text { OL } & \text { London Public Library and Art Museum } \\ \text { OLU } & \text { University of Western Ontario, London, } \\ & \text { Weldon Library, Regional } \\ & \text { History Collection }\end{array}$

ONHI Niagara-on-the-Lake Historical Society

ooA Public Archives, Ottawa Copy 185 I [i.e., I] Copy 1852 [i.e., 2]

Copy I

Copy 2

Copy 3

Copy I

Copy 2

OTLS Law Society of Upper Canada, Toronto

OTMCL Metropolitan Toronto Library
Volumes I, II

Volumes I, II

Copy I Volume II

Copy 2 Volumes I, II

Copy 3 Volumes I, II

Copy 4 Volumes I, II

Volumes I, II

Volumes I, II

Copy I Volumes I, II

Copy 3 . Volumes I, II Volumes I, II Volumes I, II Volumes I, II Volume II Volumes I, II Volumes I, II Volumes I, II Volumes I, II Volumes I, II

Copy I Volumes I, II

Copy 2 Volume I

HC 97I.I3 S5I.II [i.e., Copy 3] Volume II

OTNY North York Public Library, Willowdale, Canadiana Dept.

Volumes I, II

OTU University of Toronto

OTU-R John P. Robarts Research Library

Copy I Volumes I, II Copy 2 Volumes I, II

OTU-TF Thomas Fisher Rare Book Library Copy I Volumes I, II

Copy 2 Volume II

George Brown Library Volumes I, II

OTV Victoria University, Toronto.

E.J. Pratt Library

Volumes I, II

OTY York University, Toronto.

OTY-R Rare Book Dept.

Volumes I, II

OTY-S Scott Library

Volumes I, II

The Parts examined are in private collections. 


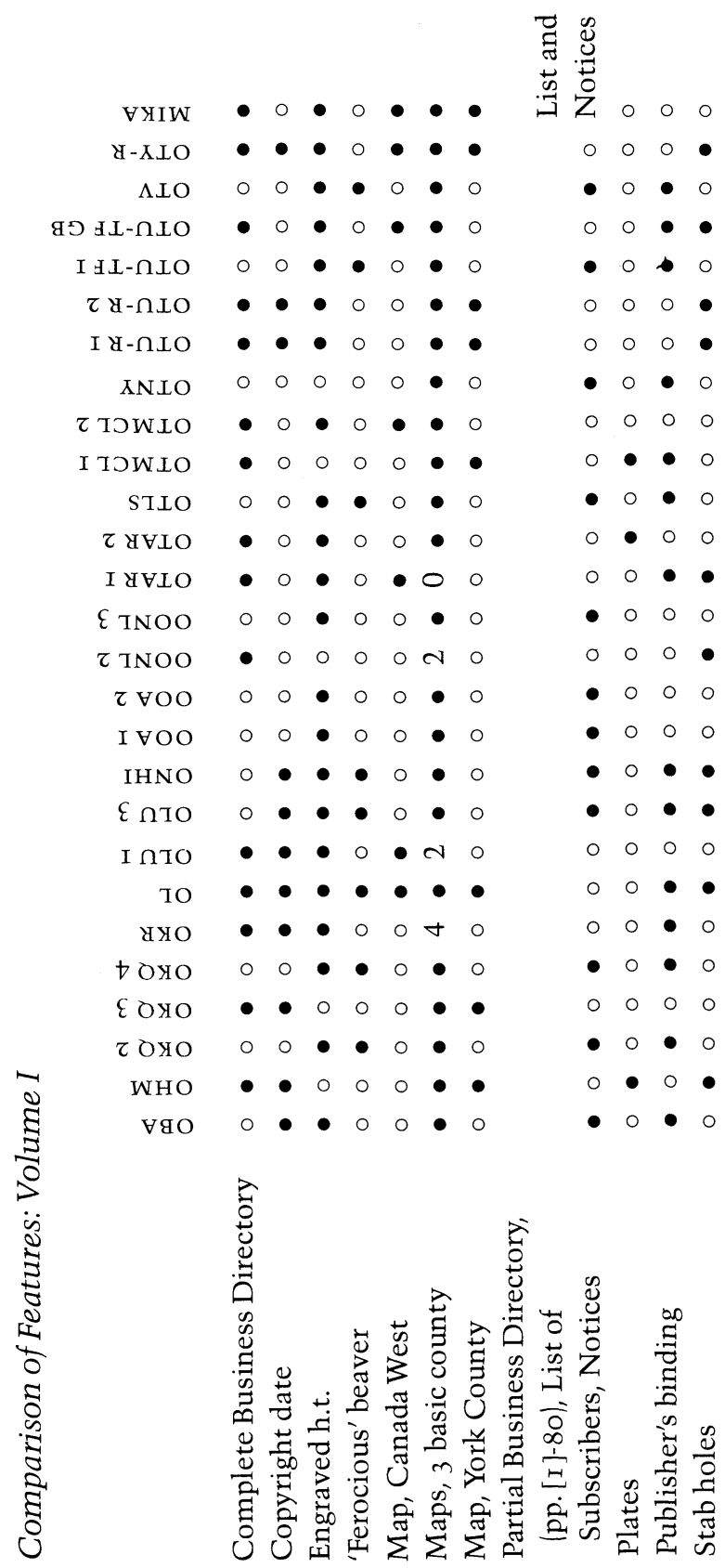




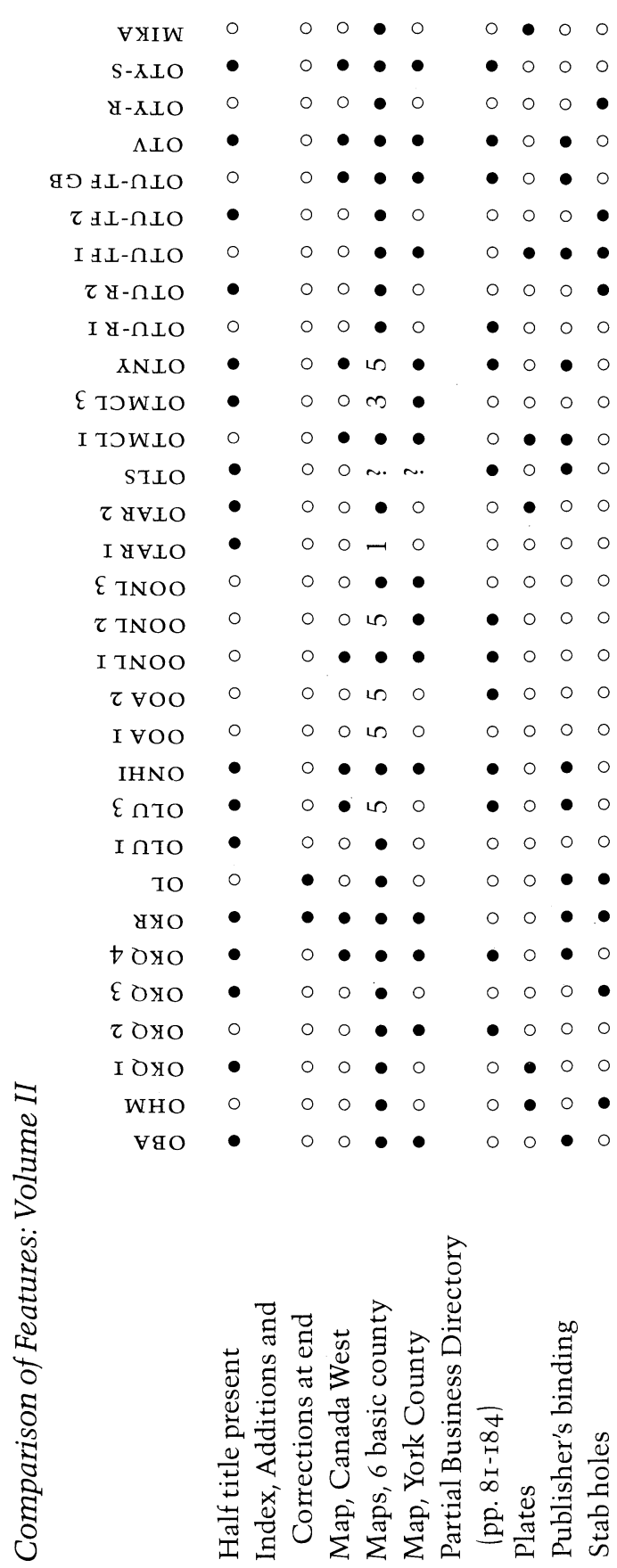




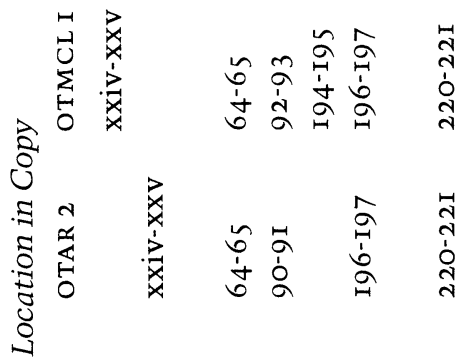

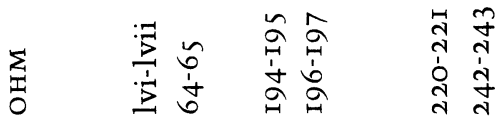

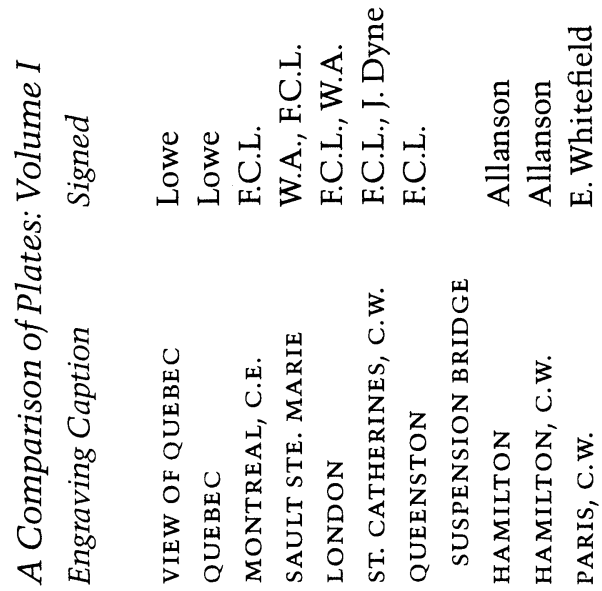




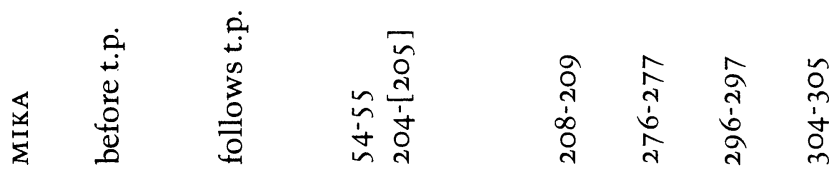

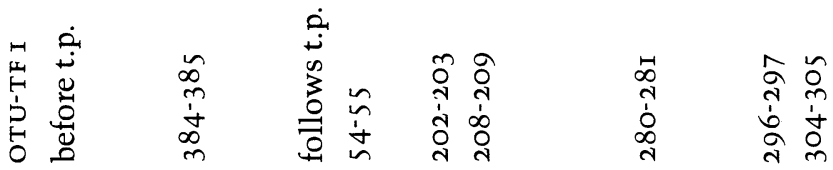

咅

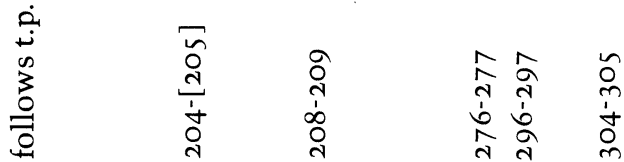

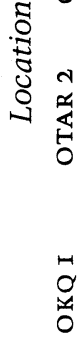

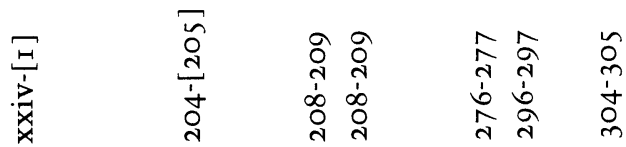

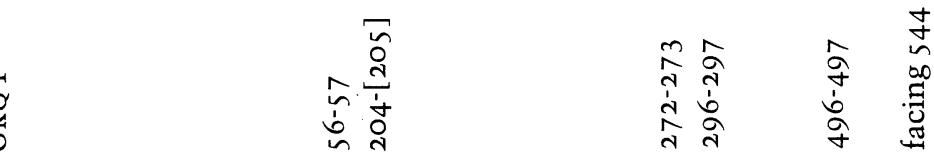

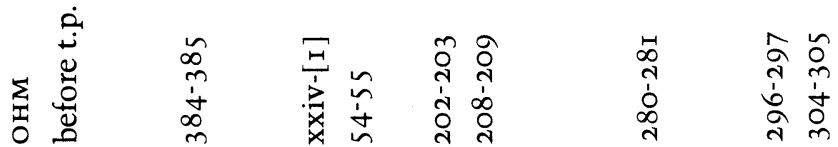

○ी

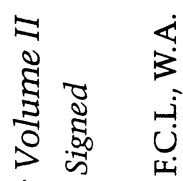

نं

is

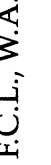

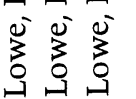

ن

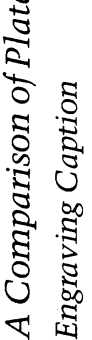

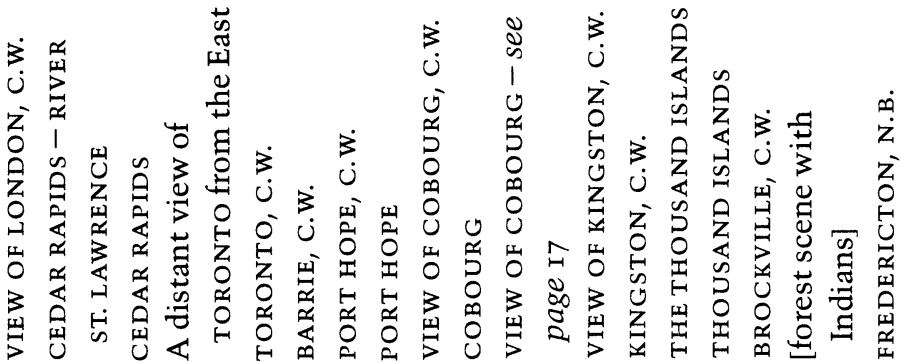




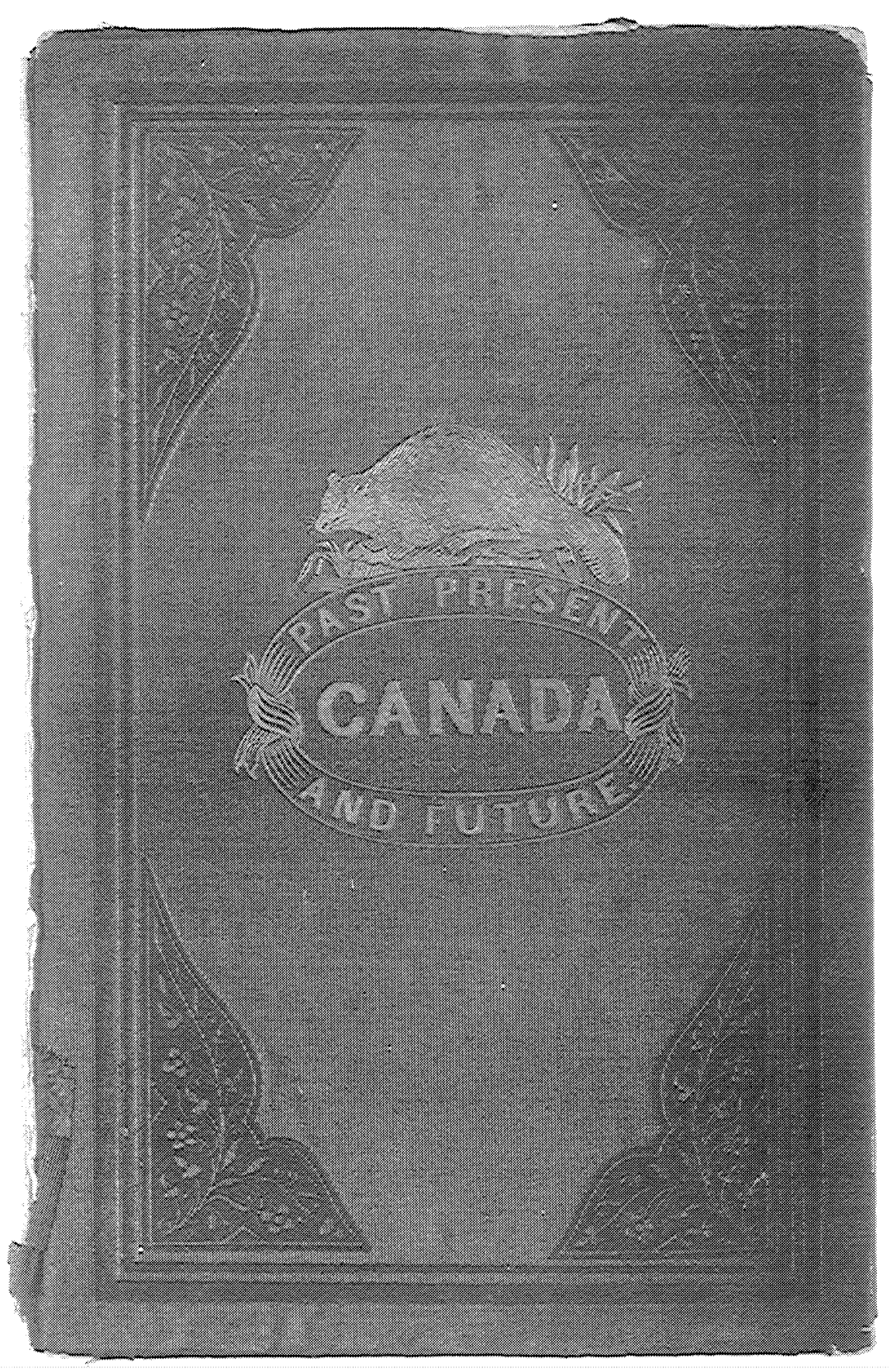

The 'happy' beaver on a leafy bank. 


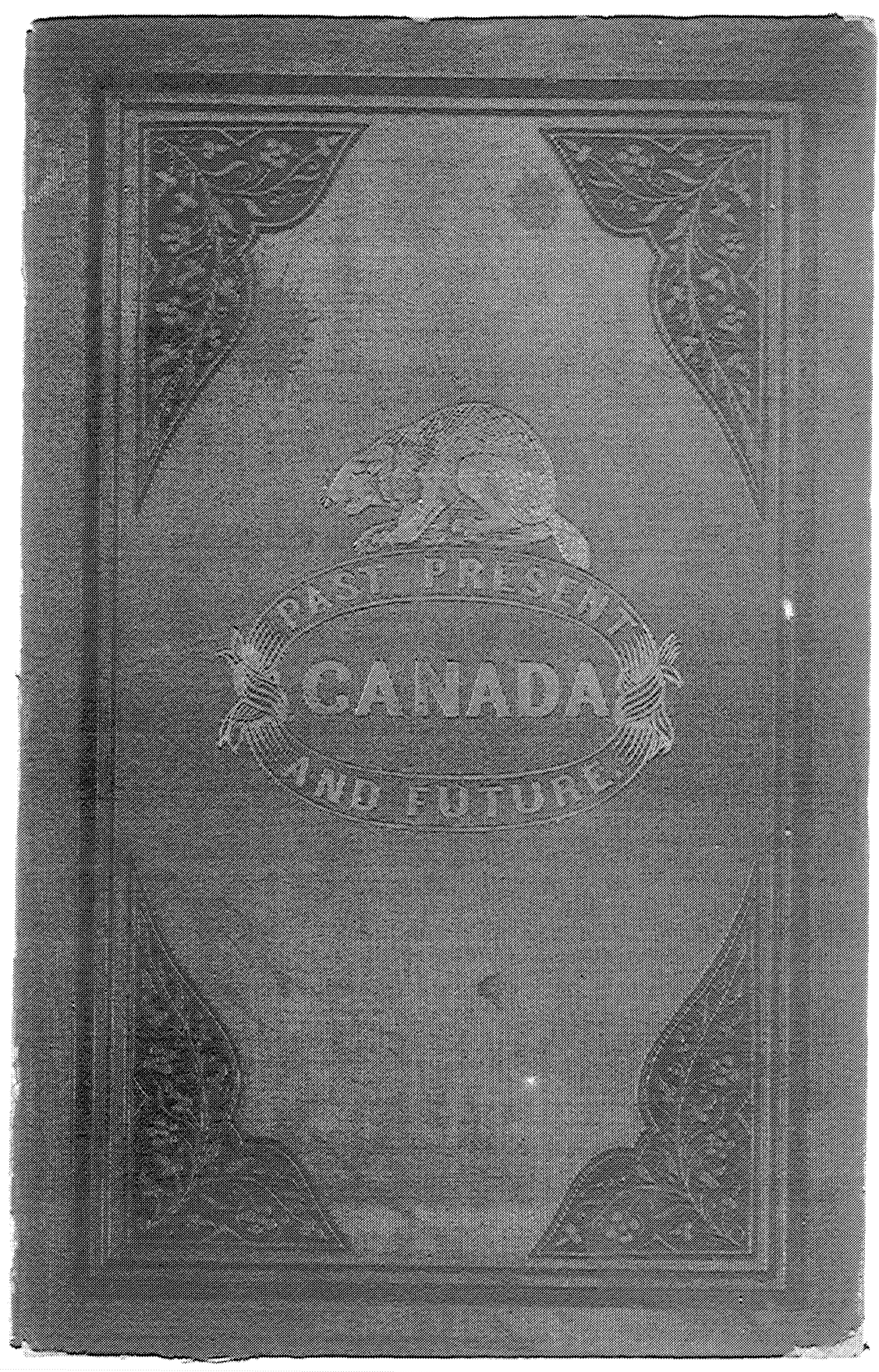

The 'ferocious' beaver. 


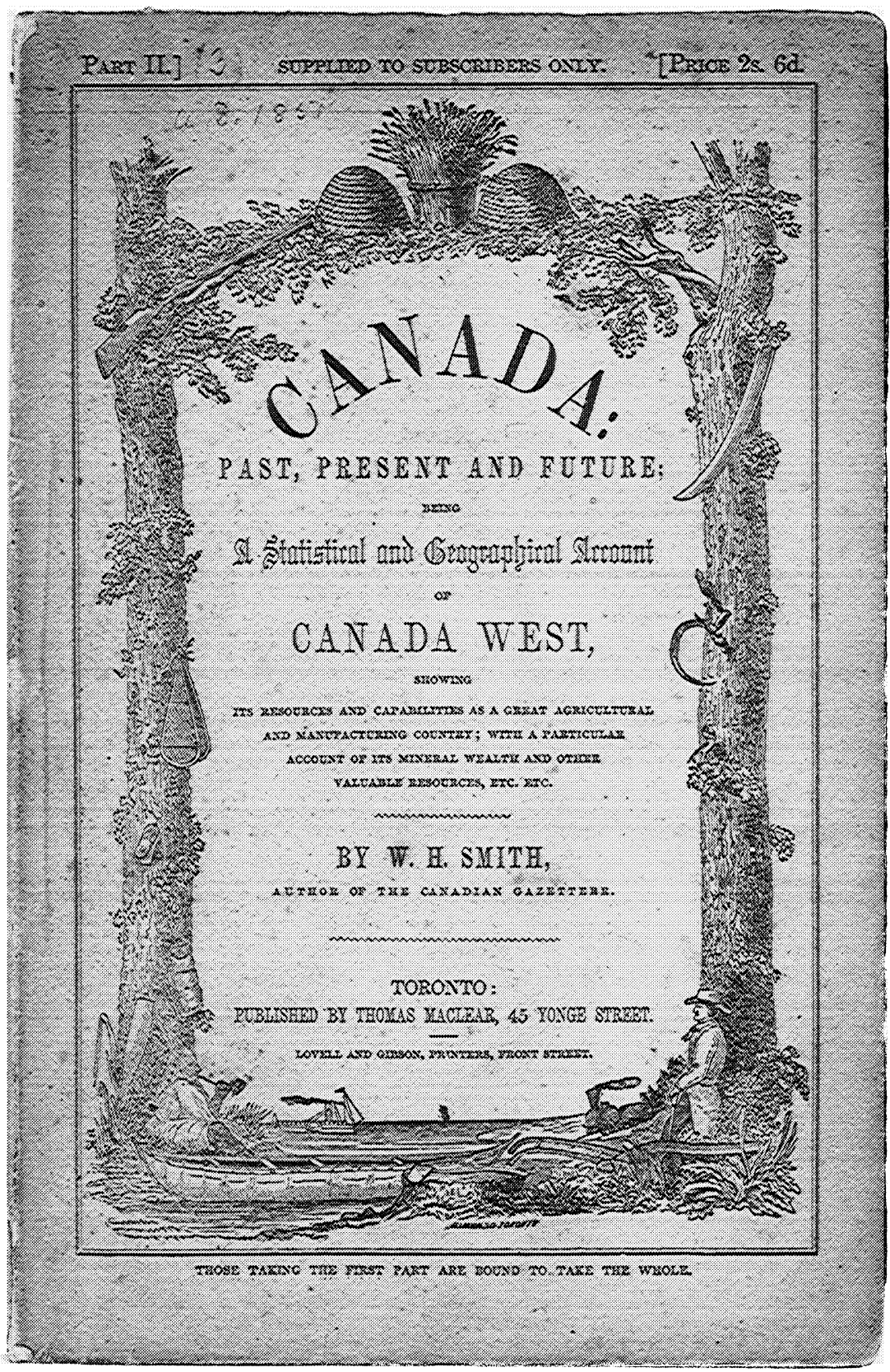

The upper wrapper of Part II. 


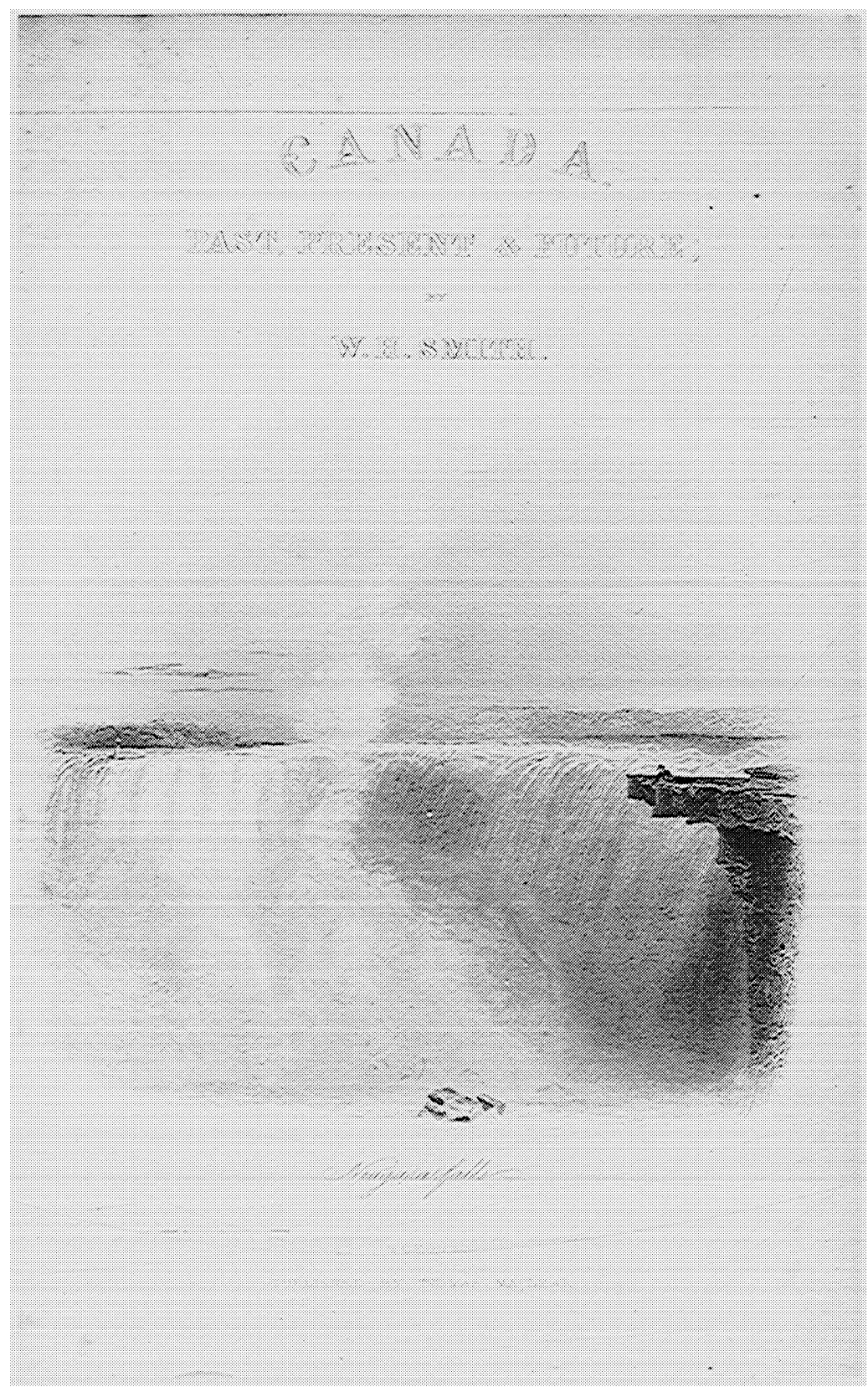

Niagara Falls, the unsigned half title of Volume I. 


\section{A N A D A; PAST, PRESENT AND FUTURE; \\ zeme}

\section{A STATSTICAL ATD GEOGRAPHCAL ACCOTXI OF CAXADA TEST,}

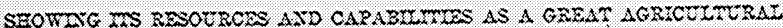
AND XATTRACTCRATG COENmET,

พxrז: A

\section{Particalar A ccomat of its Mineral Wealth and other Valabble Characteristies, Sc., se.}

BY W. H. SWITH,

AETZON OF TEZ CANADIAX GAZETTERR.

Tre Work will consist of Two Voimmes Foyal Swo, the fint of which is alreacy puto

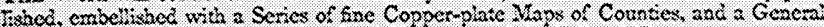
Map of Canada West; also a sne Steel Engraving of the Falts of Niagara.

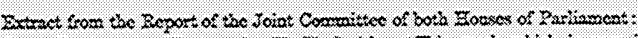

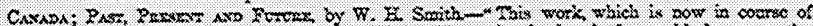

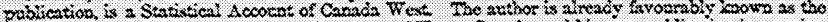

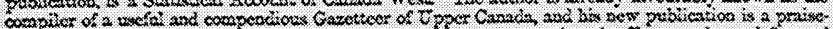

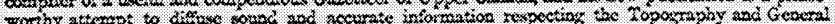

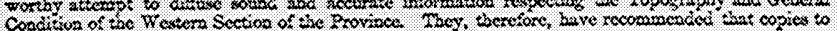
Coscition of tase Western Sectio

Shost extracts frosa a ferr cat of the very masy notices of the Press:

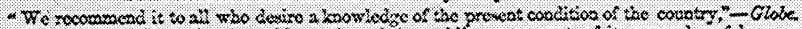

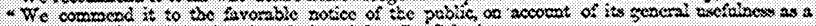

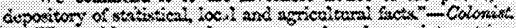

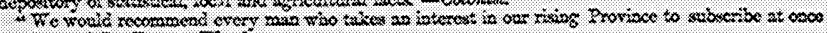

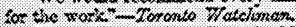

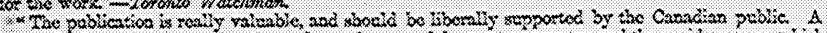

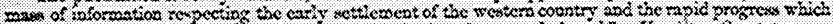

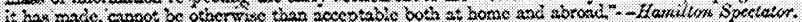

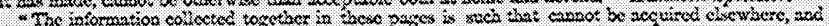

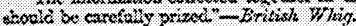

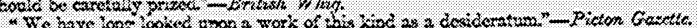

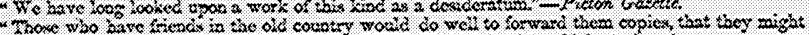

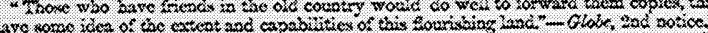

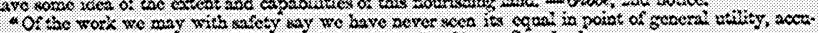

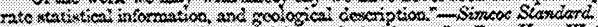

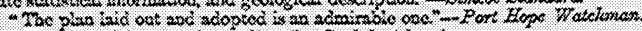

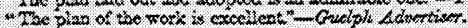

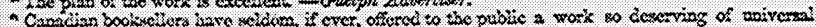

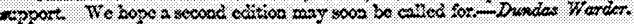

The Work is supplied to Subscribers through the mecirus of Travellers to all arailabie parts of each Provioce.

T. MACLEAR,

Puitisiver, 45 Yonge Street, Toromto.

Maclear's advertisement in Lovell's Canada Directory (I85I). 


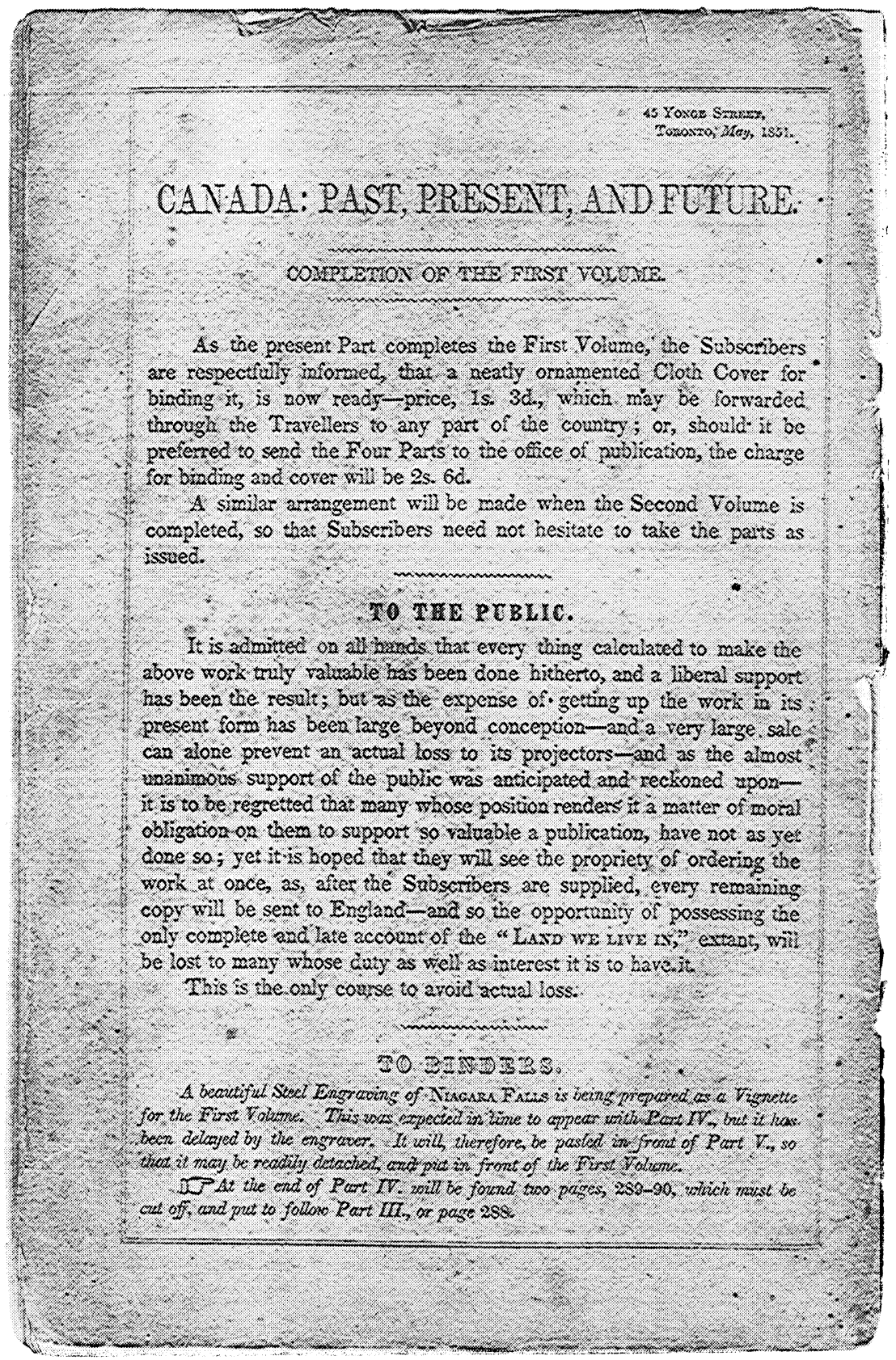

The lower wrapper of Part Iv. 


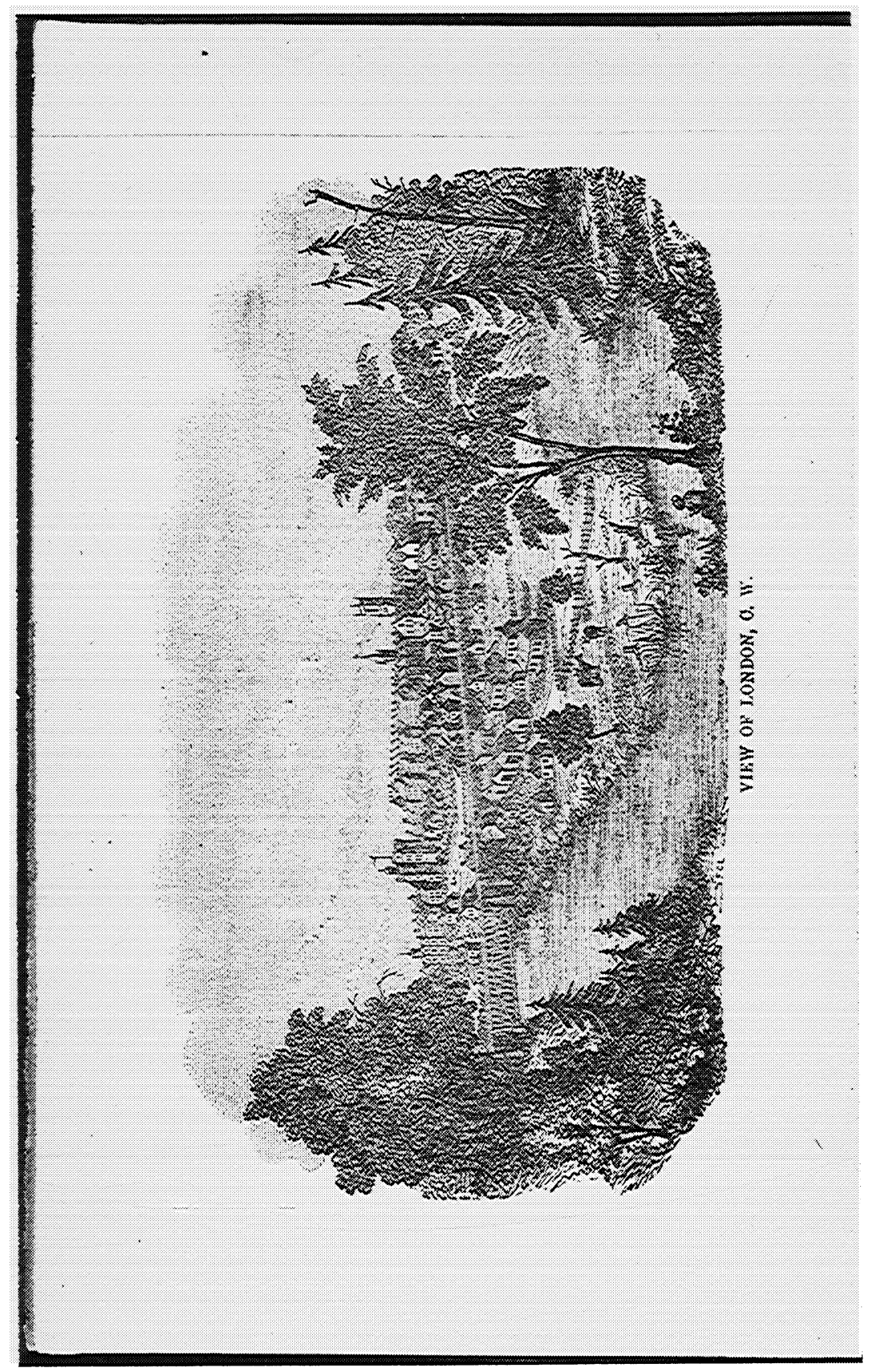

View of London, signed F.C.L. and W.A. 